\title{
Effect of Anchor Borrowers Programme (ABP) on Technical Efficiency of Beneficiary Rice Farmers in Kebbi State, Nigeria
}

\author{
Gona Ayuba*, Mahmud Abba, Maikasuwa Mohammed Abubakar \\ Department of Agricultural Economics and Extension, Kebbi State University of Science and Technology, Aliero, Nigeria
}

Email address:

ayubagona@gmail.com (G. Ayuba)

${ }^{*}$ Corresponding author

\section{To cite this article:}

Gona Ayuba, Mahmud Abba, Maikasuwa Mohammed Abubakar. Effect of Anchor Borrowers Programme (ABP) on Technical Efficiency of Beneficiary Rice Farmers in Kebbi State, Nigeria. International Journal of Agricultural Economics. Vol. 5, No. 4, 2020 , pp. 106-113. doi: $10.11648 /$ j.ijae.20200504.13

Received: May 4, 2020; Accepted: June 11, 2020; Published: July 17, 2020

\begin{abstract}
The study examined the effect of Anchor Borrowers Programme on technical efficiency of beneficiary rice farmers in Kebbi State, Nigeria. A Multi stage sampling technique was used to select 500 beneficiary and non-beneficiary rice farmers each giving a sample size of 1000 rice farmers for the study. Data collected were analyzed using stochastic frontier production function. Results from the technical efficiency estimates showed that the beneficiary rice farmers had mean value of 0.91 while the non-beneficiary farmers had mean value of 0.79 The study indicated that although both categories of farmers were inefficient in the use of existing resources, the ABP beneficiaries are more technically efficient suggesting that ABP enhances the technical efficiency of the beneficiary farmers. Results also show that for the beneficiary rice farmers, Age was significant and positively related to technical efficiency at $12 \%$ level of probability and Educational level, Farming experience, membership of cooperative, seed variety, planting technology and income level had negative relationship with technical efficiency at $1 \%$ level of probability while for non-beneficiary farmers. Age had positive relationship with technical efficiency at $1 \%$ while Educational level, Farming experience, membership of cooperative, seed variety, planting technology and income level had negative relationship with technical efficiency at $1 \%$ level of probability. It is recommended that Policies should be tailored towards inclusiveness of more farmers into the ABP. The programme should also be extended to cater for other subsectors of the Agricultural sectors such as Livestock and Aquaculture.
\end{abstract}

Keywords: Anchor Borrowers Programme, Technical Efficiency, Rice, Farmers, Kebbi State

\section{Introduction}

Rice is an important cereal crop in Nigeria, with its consumption share increasing from $15 \%$ in the 1970 s to $26 \%$ in the early 1990s [1]. Projections from the Food and Agricultural Organization [2] indicates that rice consumption grew at 4.5 percent per annum through the $2000 \mathrm{~s}$, which represented a $70 \%$ increase in total rice consumption by the end of the decade. Even though total rice production has increased over the last two decades, the increases have not been sufficient to meet the increasing demand from the rapidly growing population.

Although, annual paddy production increased from 751,000 to 1,80500 metric tons in between 2015 to 2016 .
Significant increase in rice production started in 2013, as a result of fertilizer availability under the Growth Enhancement Scheme (GES) of the Agricultural Transformation Agenda (ATA) of the Federal Government and the Fadama II and III programs in collaboration with the World Bank, Kebbi State Agricultural Development Programmes [3].

Despite a multiplicity of Federal Government of Nigeria (FGN) policies in the rice sub-sector, rice production has not matched the growing domestic demand. In 2014, rice demand was estimated at 5.9 million Metric Tons (MT) while only 2.7 million MT was locally produced, leaving a supply gap of 3.2 Million MT [1]. The main drivers of the growing demand for rice are population growth, rapid 
urbanization, raising income levels, and consumers' changing preferences in favour of parboiled rice. In fact, per capita rice production has almost doubled from 15.4 $\mathrm{kg} /$ year in the $1980 \mathrm{~s}$ to $30 \mathrm{~kg} /$ year in 2009 [4].

In an effort to boost rice production so as to tackle food security, enhance income and stem the tide of importation by conserving resources for more development, the Nigerian government has implemented a broad range of policies in the rice sector aimed at rice self-sufficiency. These programs include among others; the Presidential Initiative on Increased Rice Production (2002-2007), the Nigerian National Rice Development Strategy (NRDS, 2009-2018), the Rice Intervention Fund (RF, 2011), the Agricultural Transformation Agenda (ATA, 2011-2015), the Anchor Borrowers Program (ABP-2015).

The Central Bank of Nigeria $(\mathrm{CBN})$ in line with its development function launched the Anchor Borrowers' Programme (ABP). The programme which was launched by President Muhammadu Buhari (GCFR) on November 17, 2015 is intended to create a linkage between anchor companies involved in processing and smallholder farmers (SHFs) of the required key agricultural commodities. The program thrust of the ABP is provision of farm inputs in kind and cash (for farm labour) to small holders to boost the production of some crops such as rice, soybean and other commodities, stabilize input supply to agro-processors and address country's negative balance of payment on food. At harvest, the SHF supplies his/her produce to the agroprocessor (Anchor) who pays the cash equivalent to the farmers account. The programme evolved from consultation with stake holders comprising Federal Ministry of Agriculture and Rural Development, State Governors, millers of agricultural produce and small holder famers to boost agricultural production and non-oil exports in the face of unpredictable crude oil prices and its resultant effect on the revenue profile of Nigeria.

Despite all these intervention efforts, rice availability had continued to be a mirage with huge sums of money been expended on rice importation from foreign nations with concomitant loss in foreign exchange. Laudable as these programs are, it appears that the goal of food security on rice sustainability might not have been achieved. Anchor Borrowers Programme (ABP) was designed at the inception of President Muhammadu Buhari civilian administration as a rider to the previous programs with the aim of achieving selfsufficiency in food production, improving the income of beneficiary farmers through poverty reduction and enhancing the efficiency of production.

A lot of studies have been carried out on the performance of government programmes such as [5]; [6]; [7]; [8]. Most studies examined the performance of government programmes such as Fadama III, International Fund for Agricultural Development (IFAD), National Programme for Food Security (NSPFS), Microfinance Banks, and Bank of Agriculture. Consequently, there is paucity of published work in Nigeria generally and Kebbi State in particular on the effect of Anchor Borrowers Progrmme on technical efficiency of rice farmers.

A study directed at evaluating the achievement of ABP towards improving resource use efficiency and productivity has become necessary in order to examine the success or otherwise of ABP based on its goal. It is envisaged that proper implementation or execution of the program will engender food security, poverty reduction and revitalize the non-oil sector of the economy particularly agriculture. The study hopes to analyze the success or otherwise of the ABP. Analyzing the effect of the program on technical efficiency of rice production, might likely guide the policy makers on whether the program is successful or not. The study hopes to also provide information that would guide prospective investors on how to appropriate and use scarce resources in their investment drive towards rice farming. The sustainability of the programme in terms of its spread to other States that have not been implemented is also premised on the information that might likely emanate from the study. It is against this backdrop that this study attempts to provide answers to the following research questions;

(i) What is the relationship between inputs and output of ABP beneficiary and non-beneficiary rice farmers?

(ii) Is there any difference in the level of production efficiency between ABP beneficiary and nonbeneficiary rice farmers in the study area?

(iii) What are the determinants of technical efficiency among the ABP beneficiary and non-beneficiary rice farmers?

\subsection{Conceptual Framework}

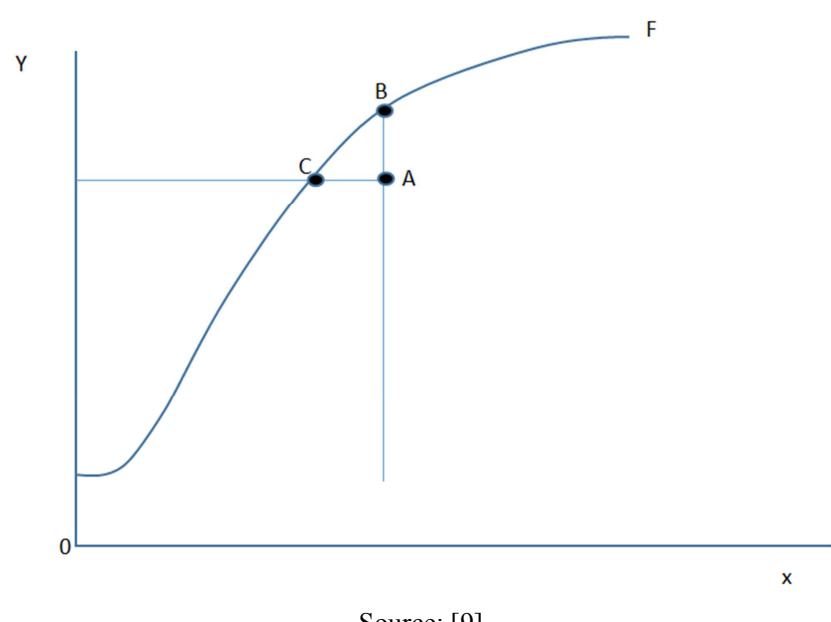

Source: [9]

Figure 1. Production Frontier and Technical Efficiency.

Production is the transformation of a given set of inputs to produce output. In the case of rice production, farmers need to combine certain measure of inputs such as rice seed, land, labour, fertilizer, agrochemicals and capital in order to produce paddy rice. Given that for paddy rice to be produced in large quality, it requires that the resources be combined/or appropriated in a definite proportion. 
Technical efficiency is the ability of the farmer to produce a given level of output using least amount of physical inputs. It signifies a peak level of performance that uses the least amount of inputs to achieve highest amount of output. Optimality is therefore required in deciding the level of inputs that are to be mixed.

Figure 1 depicts the concept of possible production set i.e. set of all resources (inputs) - output combination that are feasible. If the obtained outlet lies along the frontier (the points from $\mathrm{OF}$ ), the farm is technically efficient indicating the efficient subset of feasible production set. But if it lies below the frontier (point A), it means that it is technically inefficient because, it could increase output towards the level associated with point $\mathrm{B}$ without increasing input. Whereas points $\mathrm{B}$ and $\mathrm{C}$ represents efficient points.

The socio-economic and institutional variables are expected to influence a farmer's technical efficiency. These factors include; marital status, age, educational level, household size, farming experience, cooperativeness, seed variety, planting technology and income level.

Consequent upon the design of Anchor Borrower's Programme targeted to provide incentives both in cash and in kind, to the beneficiary rice farmers, the intervention from ABP and technical efficiency's influencing factors were anticipated to influence the technical efficiency, which the study hopes to make recommendation.

\subsection{Model Specification}

[10] and [11] proposed, almost simultaneously, but independently, a formulation within which observed deviations from the production function could arise from two sources: a) productive inefficiency, that would necessarily be negative, and b) effects specific to the firm, that could be of either sign. In order to incorporate this feature, there is need to introduce another random variable representing any statistical noise or measurement errors. In order to capture this, the stochastic model includes a composite error term that sums a two-sided error term, measuring all effects outside the firm's control, and a onesided, non-negative error term, measuring technical inefficiency. SFP model is specified as

$$
\operatorname{Ln} Y_{i}=\left(x_{i} ; \beta\right)+v_{i}-u_{i}, i=1,2 \ldots N
$$

The random error, vi, accounts for measurement error and other factors, such as the weather, strikes luck, etc, and $\mu \mathrm{i}$ is one -sided component representing technical inefficiency. Under the SFA, the error term is split into two components, allowing for both random effects and frontier efficiency, where the random effects usually follow a normal distribution and the inefficiencies a truncated normal distribution. The non-parametric approaches to efficiency measurement include the Data Envelopment Analysis and the Free Disposal Hull. The Free Disposal Hull was developed by [12] while the DEA method was first used by [13].

The parameterized stochastic frontier function both embraces technical inefficiencies of the production process and the probabilistic, random effects leading to productive inefficiency. In this sense, there appears a composite error term involving technical inefficiency and random effects. Therefore, stochastic frontier functions enable the researcher to measure both the technical efficiency sources and impact of measurement errors or factors that are not directly related with production process itself. The estimated function

appears as a frontier or benchmark with the parameter estimates indicating whether the enterprise or production unit is producing at the production or profit frontier [14]. The stochastic frontier modelling is popular among production economists because of its flexibility and the ease with which it can be used to relate economic concepts in modelling reality [15].

\section{Methodology}

\subsection{Study Area}

The study was conducted in Kebbi State, Nigeria. The choice of Kebbi State was premised on the fact that it is the State where the ABP was first launched in Nigeria. Kebbi State is located in the north-western part of Nigeria and occupies a land area of about 36,229 square kilometres with a population of about 3,630,931 [16]. Projecting this population to 2018 to be increasing at an annual population growth rate of $2.38 \%$, the state has an estimated population of about 4,938,066 people. The State lies between latitudes $10^{\circ} 05^{1}$ and $13^{\circ} 27^{1} \mathrm{~N}$ of the equator and between longitudes $3^{\circ} 35^{1}$ and $6^{\circ} 03^{1} \mathrm{E}$ of the Greenwich. This area is characteristic of Sudan savannah sub-ecological zone with distinct wet and dry seasons. Soils are ferruginous on sandy parent materials evolving from sedentary weathering of sandstones.

Over two- third of the population are engaged in agricultural production, mainly arable crop alongside cash crops with animal husbandry. The major crops cultivated include sorghum, millet, maize, cowpea, sweet potato, rice, vegetables and fruits. Cash crops grown here include soybeans, wheat, ginger, sugarcane, tobacco and gumarabic.

\subsection{Sampling Procedure and Sample Size}

Multistage sampling procedure was used to select the respondents for the study. First, the purposive selection of seven (7) Local Government areas (LGA) with the highest concentration of Anchor Borrowers Programme beneficiary farmers in the State. The LGAs are; Suru, Brinin-Kebbi, Bunza, Argungu, Augie, Dandi and Jega). Secondly, purposive selection of two villages/communities with the highest number of (ABP) beneficiary farmers from the seven (7) Local Government Areas giving a total of Fourteen (14) villages/communities. Thirdly, from each of the 14 villages /communities all together 500 beneficiary and nonbeneficiary rice farmers each were proportionately selected randomly thus, giving a sample size of 1000 rice farmers for the study. 
Table 1. Sampling Frame and the Sample Size of ABP Beneficiary Farmers in the State.

\begin{tabular}{llll}
\hline Local government areas & Sampling frame & Villages /communities of the beneficiaries & Sample size \\
\hline ARGUNGU & 7,364 & Argungu, Gulma & 74 \\
AUGIE & 5,421 & Augie, Bayawa & 54 \\
JEGA & 3,020 & Jega, Basaura & 30 \\
BUNZA & 8,446 & Bunza, Raha & 85 \\
BIRNIN KEBBI & 10,909 & Makera, Zauro & 109 \\
SURU & 11,549 & Suru, Dakin Gari & 115 \\
DANDI & 3,347 & Kamba, Dole Kaina & 33 \\
TOTAL & 50,056 & & 500 \\
\hline
\end{tabular}

Source: Kebbi State Anchor Borrowers Office, Birnin-Kebbi, 2016

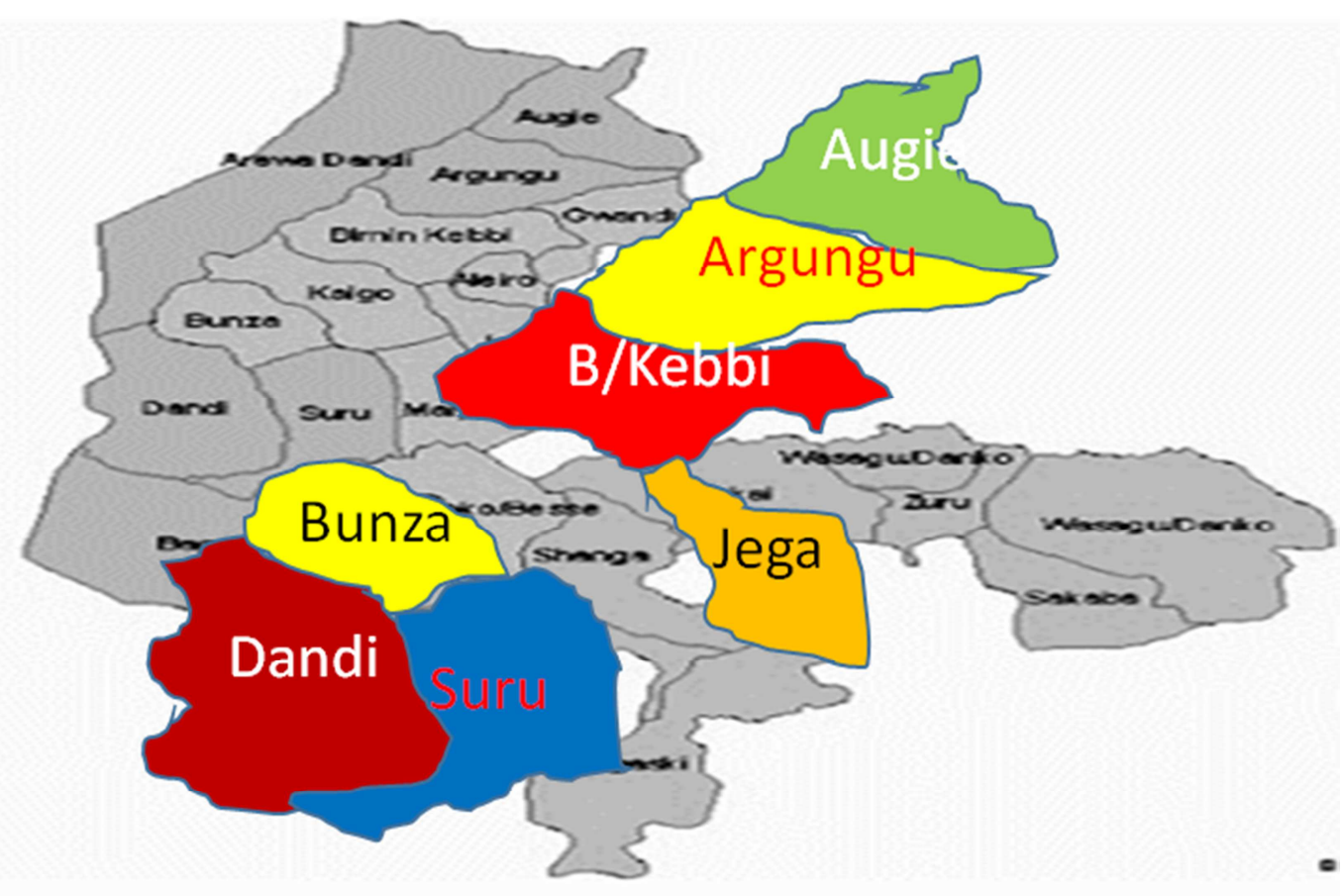

Figure 2. Map of Kebbi State showing the Study area (Local Government Areas).

\subsection{Data Collection}

The data used for the study were sourced using structured questionnaires. Data collected comprises of information on socioeconomic characteristics of ABP Beneficiary and nonbeneficiary rice farmers such as age, sex, educational level, marital status household size, income, access to ABP credit and other incentives received, farming experience etc. Data on inputs and output of respondents such as farm inputs (labour, fertilizer, seed, and insecticide/herbicide) crop output and income among rice farmers were also collected.

\subsection{Analytical Techniques}

Data collected were analyzed using stochastic frontier production function model.

The Cobb-Douglas stochastic frontier production function was used to examine the technical efficiency and the determinants of technical efficiency of ABP beneficiary and non-beneficiary rice farmers in the study area. The Cobb-
Douglass stochastic frontier production function is specified explicitly as follows:

$\ln Y=\beta_{0}+\beta_{1} \ln X_{1}+\beta_{2} \ln X_{2}+\beta_{3} \ln X_{3}+\beta_{4} \ln X_{4}+\beta_{5} \ln X_{5}+V_{i}-U_{i}(2)$

Where;

$\ln Y=$ Quantity of rice produced in $(\mathrm{Kg})$

$\mathrm{X}_{1}=$ Quantity of seed in $(\mathrm{Kg})$

$\mathrm{X}_{2}=$ Labour in (Man-days)

$\mathrm{X}_{3}=$ Quantity of fertilizer $(\mathrm{Kg})$

$\mathrm{X}_{4}=$ Quantity of Agrochemicals in (Liters)

$\mathrm{X}_{5}=$ Depreciation of Capital in ( ()

$\mathrm{V}_{\mathrm{i}}-\mathrm{U}_{\mathrm{i}}$ are error terms defined as $\mathrm{v}_{\mathrm{i}}-\mathrm{u}_{\mathrm{i}}$

$\mathrm{V}_{\mathrm{i}}=$ are random variables which are assumed to be independent of $\mathrm{U}_{\mathrm{i}}$, identical and normally distributed with zero mean and constant variance $\left.\mathrm{N}\left(0, \sigma^{2} v\right)\right)$ ]

$\mathrm{U}_{\mathrm{i}}=$ which are non-negative random variables which are assumed to account for technical inefficiency in production and are often assumed to be independent of $\mathrm{V}_{\mathrm{i}}$ such that $\mathrm{U}_{\mathrm{i}}$ is the non-negative truncated (at zero). 
$\mathrm{U}_{\mathrm{i}}$ is defined as:

$$
\mathrm{U}_{\mathrm{i}}=\delta_{0}+\delta_{1} \mathrm{Z}_{1}+\delta_{2} \mathrm{Z}_{2}+\delta_{3} \mathrm{Z}_{3}+\delta_{4} \mathrm{Z}_{4}+\delta_{5} \mathrm{Z}_{5} \delta_{6} \mathrm{Z}_{6+} \delta_{7} \mathrm{Z}_{7}+\delta_{8} \mathrm{Z}_{8+} \delta_{9} \mathrm{Z}_{9+} \delta_{10} \mathrm{Z}_{10+} \mathrm{V}_{\mathrm{i}}-\mathrm{U}_{\mathrm{i}}
$$

Where:

$\mathrm{U}_{\mathrm{i}}=$ Technical Inefficiency

$\mathrm{Z}_{1}=$ Gender $(1$ for male, 0 otherwise $)$

$\mathrm{Z}_{2}=$ Marital status (1 for married, 0 otherwise)

$Z_{3}=$ Age (years)

$\mathrm{Z}_{4}=$ Educational level (Years)

$Z_{5}=$ House hold size (Number)

$\mathrm{Z}_{6}=$ Farming experience (Years)

$Z_{7}=$ Membership of Cooperative (Dummy variable; 0 for nonmember, 1 for membership)

$\mathrm{Z}_{8}=$ Seed variety ( 1 for improved, 0 otherwise)

$Z_{9}=$ Planting technology (1 for Broadcasting, 0 otherwise)

$\mathrm{Z}_{10}=$ Income level $(\mathrm{N})$

$\mathrm{V}_{\mathrm{i}}-\mathrm{U}_{\mathrm{i}}=$ as earlier defined

$\delta_{0}-\delta_{10}=$ Parameters to be estimated

\section{Results and Discussion}

\subsection{Input-Output Relationship}

Result in Table 2 showed the Maximum Likelihood Estimates (MLE) for the production frontier. The estimated parameters of sigma-squared were 0.0280 and 0.0875 for ABP beneficiary and non- beneficiary rice farmers, respectively. These values were significantly different from zero at $1 \%$ level of probability, indicating correctness of the specified distributional assumption of the composite error term and goodness of fit. The generalized likelihood ratio obtained for the two groups, 183.67 and 147.78 for ABP beneficiary and non-beneficiary rice farmers, respectively exceeds the critical chi-square values at $1 \%$ level of probability. These values maximize the joint densities in the estimated model. The implication of this is that Cobb-Douglass production functional form adopted in the estimation of this study is an adequate representation of the data.

\subsection{Average Statistics of the Farmers}

The average statistics of the farmers are summarized and presented in Table 2.

Table 2. Summary statistics of variables for the sampled mean of rice farmers.

\begin{tabular}{lll}
\hline Variables & $\begin{array}{l}\text { Mean ABP } \\
\text { Beneficiary }\end{array}$ & $\begin{array}{l}\text { Mean Non- } \\
\text { Beneficiary }\end{array}$ \\
\hline Age (years) & 44.00 & 49.00 \\
Years of Experience (Years) & 16.00 & 22.00 \\
No of years in schools (years) & 8.00 & 6.00 \\
Quantity of fertilizer (Kg) & 300.00 & 100.00 \\
Quantity of seed (Kg) & 94.20 & 105.40 \\
Household size (number) & 6.00 & 11.00 \\
Quantity of chemicals (liters) & 8.00 & 4.00 \\
Labour (man-days) & 58.37 & 79.40 \\
Output in (Kg) (Naira) & 296.020 .00 & $200,763.30$ \\
Planting materials (Naira) & $7,203.67$ & $8,374.79$ \\
Capital (Naira) & $1,059.92$ & $1,389.98$ \\
\hline
\end{tabular}

Source: Field survey, 2018

Result in Table 2 indicates that a typical ABP beneficiary rice farmer was 44 years with 16 years of experience, 8 years of schooling and household size of 6 . On the average he employed about 58 man-days of labour per hectare per annum, spent $\$ 7,203.67$ on planting materials, and $\$ 1,059.92$ on capital inputs and produced an output of $\$ 296,020.00$ per year. An average non-beneficiary rice farmer was 49 years with 22 years of experience, 6 years in schooling and household size of 11 . On the average, a farmer employed about 79 man-days of labour per hectare per annum, spent $\$ 8,374.79$ on planting materials and $\$ 1,389.98$ on capital inputs and produced an output of $\$ 200,763.30$.

Table 3. Maximum Likelihood Estimate Results of Stochastic Frontier Production Function.

\begin{tabular}{|c|c|c|c|c|c|c|}
\hline \multicolumn{3}{|l|}{ ABP Beneficiary } & \multicolumn{4}{|c|}{ Non-Beneficiary } \\
\hline Variable & Coefficient & Standard Error & t-ratio & Coefficient & Standard Error & t-ratio \\
\hline Constant $\left(\beta_{0}\right)$ & 7.9442 & 0.1345 & $16.36^{* * *}$ & 0.0097 & 2.1137 & $73.40 * * *$ \\
\hline Seed $\left(\mathrm{X}_{1}\right)$ & 0.1418 & 0.7136 & $8.02 * * *$ & -0.0236 & 0.2008 & $46.09 * * *$ \\
\hline Labour $\left(\mathrm{X}_{2}\right)$ & 0.2957 & 0.8901 & $4.41 * * *$ & 0.0050 & 1.1915 & $24.61 * * *$ \\
\hline Fertilizer $\left(\mathrm{X}_{3}\right)$ & 0.0509 & 1.0090 & 14.07 & -0.1002 & 0.8871 & $66.88 * * *$ \\
\hline Agrochemicals $\left(\mathrm{X}_{4}\right)$ & 0.2365 & 2.6731 & $3.47 * * *$ & 0.0144 & 0.4352 & $0.0144 * * *$ \\
\hline Capital $\left(\mathrm{X}_{5}\right)$ & 0.3031 & 0.1345 & $7.81 * * *$ & 8.2734 & 3.7243 & $12.00 * * *$ \\
\hline \multicolumn{7}{|l|}{ Diagnostic statistics } \\
\hline Sigma squared $\left(\sigma^{2}\right)$ & 0.0280 & 1.320 & $14.74 * * *$ & 0.0875 & 10321 & $1591 * * *$ \\
\hline $\operatorname{Gamma}(\gamma)$ & 0.3220 & 2.064 & 8.84 & 0.799 & 2.032 & $84.105^{*}$ \\
\hline LR test & $183.67 * * *$ & & & $147.79 * * *$ & & \\
\hline log likelihood function & $14.96^{* * *}$ & & & $183.48 * * *$ & & \\
\hline
\end{tabular}

Source: Field survey, 2018

$* * *, * *, *$ Significant at $1 \%, 5 \%$ and $10 \%$, respectively

Result in Table 3 reveal the estimated values of gamma statistics obtained for ABP beneficiary and non- beneficiary rice farmers were 0.322 and 0.799 , respectively implying that technical inefficiency effects 
were present among ABP beneficiary and non-beneficiary rice farmers in the study area. Table 3 presents the estimated parameter of seed among the ABP beneficiary rice farmers which was positive and significant at $1 \%$ level of probability. On the other hand, seed was significant and negatively related to output among the non-beneficiary rice farmers. The positive coefficient obtained for seed among the beneficiary rice farmers implies that increase in the use of this variable input will lead to a corresponding increase in the yield while in the case of non-beneficiaries if more seed is put into production the yield will decrease. The fall in the yield with further increase in seed for non-beneficiary farmers could be attributed to their source of seed which is mostly from previous harvest and their access to extension information on the use of recommended quantity of seed. The result is similar to the studies by [17], who found a positive and significant coefficient for seed among beneficiaries of Fadama II Project in Niger State.

The estimated parameter of labour obtained for ABP beneficiary and non-beneficiary rice farmers were 0.295 and 0.005 , respectively. These values were positive and significant at 1 percent level of probability. The implication of these positive coefficients is that the yield of the two groups of farmers would increase with an increase in the use of labour input. Farm production in the area is subsistence and labour intensive therefore, the result obtained with respect to labour implied that labour is an important factor of production. The result is in line with the study conducted by [18] on profitability and technical efficiency among beneficiary crop farmers of National Fadama II Project in Adamawa State. They found labour to be positive and significant in affecting food crop output. [17] noted that labour is second most import factor of production in rice production among beneficiaries and non-beneficiaries of National Fadama II Project. [19] listed labour and herbicides among inputs contributing significantly to output.

The coefficient of fertilizer exerts positive and significant influence on the yield of ABP beneficiary rice farmers in the study area while a negative influence was obtained for nonbeneficiary farmers. This implied that additional use of fertilizer with existing technology will reduce the yield of non-beneficiaries. On the other hand, an increase in the use of fertilizer input among beneficiary farmers will increase their yield. Accessibility to information on recommended rate of fertilizer could determine the quantity of rice yield. The variation in the use of fertilizer could also be determined by supply and price.

The results further showed that agrochemicals were positively related to the yield of rice by the ABP beneficiary rice farmers at $1 \%$ level of significance, while in the case of non-beneficiaries it was negative at $1 \%$ level. The implication of the positive coefficient obtained for the beneficiaries is that output will increase with additional increase in the use of agrochemicals while a further increase in the use of this input will reduce the output of nonbeneficiaries. The reason for the ineffectiveness of agro- chemicals among the non-beneficiary farmers could be nonadherence to specification on mixing formula and wrong time of application. The agrochemical could be washed away by rain immediately after its application, making it ineffective. The estimated parameters of capital were positive and significantly related to yield of both $\mathrm{ABP}$ beneficiary and non-beneficiary rice farmers. The implication of this is that increase in the amount of capital committed to production by the farmers will increase yield. Capital is required in all the stages of production process and needed to procure other production inputs.

\subsection{Frequency Distribution of Technical Efficiency among ABP Beneficiary and Non-Beneficiary Rice Farmers}

Table 4. Frequency distribution of technical efficiency estimates.

\begin{tabular}{lll}
\hline Technical efficiency range & ABP beneficiary & Non- beneficiary \\
\hline $0.31-0.40$ & - & $19(3.8)$ \\
$0.41-0.50$ & - & $6(1.2)$ \\
$0.51-0.60$ & - & $8(1.6)$ \\
$0.61-0.70$ & - & $106(21.2)$ \\
$0.71-0.80$ & $3(0.6)$ & $52(10.4)$ \\
$0.81-0.90$ & $133(26.5)$ & $263(52.6)$ \\
$0.91-1.0$ & $364(72.9)$ & $46(9.2)$ \\
Total & $500(100)$ & $500(100)$ \\
Mean & 0.91 & 0.79 \\
Minimum & 0.77 & 0.36 \\
Maximum & 0.99 & 0.94 \\
t-value & $21.82^{* * *}$ & \\
\hline
\end{tabular}

Source: Field survey, 2018

Figures in parentheses are percentages $* * * \mathrm{P}<0.01$

Results in Table 4 shows the frequency distribution of technical efficiency estimates for ABP beneficiary and nonbeneficiary rice farmers. It was revealed that there is variation in the technical efficiency index of farmers and this ranged from a minimum of 0.71 to a maximum of 0.99 for ABP beneficiaries while the minimum and maximum values of technical efficiency were between 0.31 and 0.94 for non-beneficiaries. The mean values were 0.91 and 0.79 for ABP beneficiary and non-beneficiary rice farmers, respectively. The implication of the results is that the average beneficiary farmer requires $9 \%$, that is, $\{1-$ $(0.91 / 0.99) \times 100\}$ cost savings to attain the status of the most efficient farmer. Similarly, an average non- beneficial farmer will need to save his cost by $16 \%$, that is, $\{1-$ $(0.79 / 0.94) \times 100\}$ in order to attain the status of the most efficient farmer. The least performing beneficiary farmer would need $22 \%$ cost savings which is $\{1-(0.71 / 0.99 \times 100\}$ and non-beneficiary farmer would need $67 \%$ cost saving that is $\{1-(0.31 / 0.94 \times 100\}$ to become the most efficient farmer. Results revealed that even though ABP beneficiary and non- beneficiary rice farmers are not fully efficient in the use of existing resources, results suggests that ABP beneficiary farmers are better off in the use of existing resources. This implies that ABP enhances the technical efficiency of the beneficiary farmers. 


\subsection{Determinants of Technical Efficiency}

Table 5. Factors influencing technical efficiency among rice farmers.

\begin{tabular}{lllllll}
\hline ABP Beneficiary & \multicolumn{7}{c}{ Non-Beneficiary } \\
\hline Variable & Coefficient & Standard Error & t-ratio & & Coefficient & Standard Error \\
\hline Constant & 1.0604 & 2.134 & $775.36^{* * *}$ & -0.7675 & 0.238 & $1090^{* * *}$ \\
Gender & -0.0090 & 0.796 & -1.38 & -0.1393 & 2.466 & -0.74 \\
Marital status & 0.0385 & 1.003 & 1.52 & -0.0588 & 3.977 & -1.30 \\
Age & 0.0097 & 1.2008 & $25.24^{* * *}$ & 0.0091 & 5.099 & $6.28^{* * *}$ \\
Educational level & -0.003 & 0.224 & $-17.82^{* * *}$ & 0.0334 & 4.488 & $4.31^{* * *}$ \\
Household size & -0.0049 & 1.054 & -1.42 & -0.0060 & 2.134 & -1.10 \\
Farming experience & -0.0085 & 0.567 & $-20.42^{* * *}$ & -0.0042 & 1.111 & $-2.61^{* * *}$ \\
Cooperativeness & -0.0357 & 2.333 & $-78.88^{* * *}$ & -0.0683 & 3.543 & $-3.27^{* * *}$ \\
Seed variety & -0.0091 & 2.006 & $-12.07^{* * *}$ & -0.0165 & 3.677 & $-2.49^{* * *}$ \\
Planting technology & -0.0048 & 3.442 & $-20.74^{* * *}$ & -0.0415 & 1.211 & $-4.25^{* * *}$ \\
Income level & -0.0028 & 3.300 & $-92.33^{* * *}$ & -0.0098 & 2.242 & $-2.86^{* * *}$ \\
\hline
\end{tabular}

Source: Field survey, 2018

$* * *, * *, *$ Significant at $1 \%, 5 \%$ and $10 \%$, respectively

Results in Table 5 shows the determinants of technical efficiency among ABP beneficiary and non-beneficiary rice farmers. As shown in Table 3, the coefficient of age is statistically significant and maintained the right a priori positive relationship with technical efficiency for the two groups of farmers. The older the farmer becomes, the more his efficiency drops. This is similar to the findings by [20].

Education is statistically significant and negatively related to technical efficiency. This is according to $a$ priori expectations and tallies with the findings by [20] and [21] Education exposes the farmers to new knowledge about new farming technologies. The more educated a farmer the less inefficient they become. According to [22], education is one of the socio - economic variables that greatly affects farmers' decision to accept and adopt modern farming technologies.

Experience in farm production was negative and significant at $1 \%$ percent for the two groups of farmers. This shows that increase in experience in farm production would increase technical efficiency and reduce technical inefficiency. Farmers' experience could be associated with skill accumulation which could enhance productivity and resource allocation thereby reduce technical inefficiency. The impact of farming experience on inefficiency reduction could be attributed to the use of modern farming techniques as against old traditional practices of production. Farming experience of a farmer determines his ability to make effective farm management decisions, not only adhering to agronomic practices but also with respect to input combination or resource allocation. Farming experience is expected to influence farm production efficiencies because of accumulation of skills. [23] noted that the longer a person stays on a particular job, the better his job performance tends to be. The result suggests that job performance in farm production would be better under long years of experience.

Membership of cooperative and income were significant at $1 \%$ level for both beneficiaries and non-beneficiaries. The negative coefficient for membership imply that membership of association reduces technical inefficiency (increases technical efficiency) in farm production. Membership of association could afford the farmers the opportunity of sharing information on modern farming practices by interacting with other farmers. Membership of cooperative can enhance the accessibility of farmers to credit facility and serve as a medium for exchange of ideas that can improve their farm activities

Seed variety and Planting technology showed a negative relationship with predicted technical efficiency and these variables are significant at $1 \%$ level of probability for ABP beneficiary and non-beneficiary rice farmers.. This indicates that farmers' level of technical efficiency would increase as improved seed variety and improved farming technology are brought to bear in production. The significance of seed variety and new planting technology are premised on their tendency to give higher yield in production. This is in consonance with the study by [1] in their study on profit efficiency among small scale irrigated tomato producers in Kebbi State, Nigeria

\section{Conclusion}

The results indicated that although both ABP beneficiaries and non-beneficiaries were inefficient in the use of existing resources, however, ABP beneficiaries are more technically efficient with a mean value of 0.91 compared with the nonbeneficiaries having a mean technical efficiency estimate of 0.79 It is concluded that ABP enhances the technical efficiency of the beneficiary rice farmers. Results from the study further revealed that the factors affecting technical efficiency of both ABP beneficiary and non-beneficiary rice farmers include; Age, Educational level, Farming experience, membership of cooperative, seed variety, planting technology and income level. 


\section{Recommendation}

Based on the results of the study which revealed that ABP enhances the technical efficiency of the beneficiary rice farmers, it is recommended that ABP policy should be designed towards inclusiveness of all categories of farmers in order to enhance food productivity in the State and the country at large. The programme should also be extended to cater for other subsectors of the Agricultural sector such as Livestock, Aquaculture, Forestry among others.

\section{References}

[1] Adebayo, E. F. (2006). Resource-Use Efficiency and multiple Production Objectives of Dairy Pastoralists in Adamawa State, Nigeria. Unpublished Ph.D Thesis, University of Ibadan, Nigeria.

[2] Aigner, D. I., Lovell C. A. K., and Schmidt, P. (1977). "Formation and Estimation of Stochastic Frontier Production Function Models." Journal of Econometrics 6: 21 - 37.

[3] Alabi R. A. (2003). Human Capital as Determinant of Technical Efficiency of Cocoa-Based Agroforestry System. Food, Agriculture and Environment 1 (3): 277 - 281.

[4] Alkire, S. and Foster J. (2007) Counting and Multidimensional Poverty Measurement. OPHI working paper No. 7, December 2007.

[5] Alston J. M., and Parde, P. G. (2001). Attribution and other Problems in Assessing Returns to Agricultural R\&D. Agricultural Economics, 25, 141-152.

[6] Anon, C. T. (2006). Farmers Adoption of New Technology. University of Nigeria Press. Nsukka-Nigeria. Pp 123-131.

[7] Awoyemi, T. T., Odozi, J. C., Otekunrin, O. A., and Eherim, N C., (2014). Efficient Resources Use. Does Human Capital Matter? The Case Study of Cassava Production Famer in Oyo State, Nigeria. International Journal of Agricultural and Rural Development 2014 (3) 1973-1983.

[8] Binuyo, G., Abdulrahman, S. and Timothy, A. J. (2016). Technical Efficiency of Rain-fed Lowland Rice Production in Niger State, Nigeria. Asian Journal of Agricultural Extension, Economics \& Sociology 9 (4): 1-12.

[9] Charles, A. A. (2003). Adoption of Animal Traction Technology in the Builsa District of Upper East Region of Ghana. Published M. Phil Thesis Submitted to the Department of Agricultural Extension University of Ghana, Legon. http://ugspace.ug.edu.gh.

[10] Coelli T. J. (1996) A Guide to DEAP Version 2.1: A Data Envelopment Analysis (computer) Program. CEPA Working Papers No. 8/96, Department of Econometrics, University of New England, Armidale.

[11] Coelli T, Rao D. S. P. and Battese, G. E. (1998) " $A n$ Introduction to Efficiency Analysis. London: Kluver Academic Publisher.
[12] Ezeokeke, C., Anyanwu, N., and Okoro, V. (2012). Impact of Fadama II Project on Feed, Food and Poverty in Imo State, Nigeria. International Journal of Applied Sociology, 2 (3), 2224.

[13] Fakayode, S. B. (2009) "Technical Efficiency and Factor Productivity in Upland and Low Land Rice Production in Kwara State, Nigeria. A PhD Thesis Submitted to the Department of Agricultural Economics, University of Ilorin.

[14] Food and Agricultural Organization (FAO) (2009) About the Special Programme for Food Security. www.fao.org15/12/2009.

[15] Gona, A. Maikasuwa, M. A. and Tomo, I. K. (2020). Profit Efficiency Among Small Holder Irrigated Tomato Farmers in Kebbi State, Nigeria. European Journal of Agriculture and Forestry 1 (3): 87-92.

[16] Girei, A. A. And Dire, B. (2013). Profitability and Technical Efficiency among the Beneficiary Crop Farmers of National Fadama II Project in Adamawa State, Nigeria. Net Journal of Agricultural Science 1 (3): 87-92.

[17] Kadiri, F. A.; Eze, C. C; Orebiyi, J. S; Lemchi, J. I; Ohajianya, D. O; Nwaiwu, I. U (2014) Technical Efficiency In Paddy Rice Production In Niger Delta Region Of Nigeria Global Journal of Agricultural Research Vol. 2, No. 2, PP. 33- 43, June 2014 Published by European Centre for Research Training and Development UK (www.eajournals.org).

[18] Kebbi Agricultural and Rural Development Authourity (KARDA) (2017) Yearly Report.

[19] Kolawale, O and Ojo, S. (2007). Economic Efficiency of Small Scale Food Crop Production in Nigeria: A Stochastic Frontier Approach. Journal of Social Sciences. 14 (2): 123-30.

[20] Kopp, R. J., (1981). The Measurement of Productive Efficiency: A Reconsideration, The Quarterly Journal of Economics, 96 (3): 477-503.

[21] Mallam, M., Agbo, F. U. And Ebe, F. E. (2014). Resource Use Efficiency among Beneficiaries and Non-Beneficiaries of Fadama Rice Project in Niger State, Nigeria. International Journal of Agricultural Research 9 (6): 294-303.

[22] Meeusen, W. and Van den Broeck J. (1997). "Efficiency Estimation from Cobb- Douglas Production Functions with Composed Error", International Economic Review. 18: 435444.

[23] National Population Commission (NPC) (2006). Population Figure. Federal Republic of Nigeria, Abuja. Retrieval from https://www.npc.gov.ng.

[24] Nwaru, J. C. Onyenweaku, C. E. and Nwosu, A. C. (2006). Stochastic Frontier Production Functions and Measurement of the Technical Efficiency of Credit using and Non-Credit using Arable Crop Farmers in Imo State of Nigeria. ASSET An International Journal 6 (2): 333-346.

[25] Onu, J. J., Amaza P. S and Okunmadewa, F. Y (2000) "Determinants of Cotton Production" Economic Efficiency in Business and Economics Research, 1 (2): 35-40. 